\title{
Effects of land management on large trees and carbon stocks
}

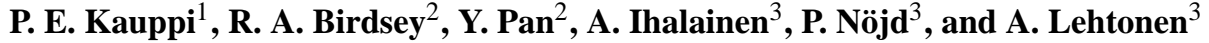 \\ ${ }^{1}$ Department of Environmental Sciences, P.O. Box 65, 0014, University of Helsinki, Helsinki, Finland \\ ${ }^{2}$ USDA Forest Service, Northern Research Station, Newtown Square, PA, USA \\ ${ }^{3}$ Natural Resources Institute Finland (Luke), P.O. Box 18, 01301 Vantaa, Finland
}

Correspondence to: P. E. Kauppi (pekka.kauppi@ helsinki.fi)

Received: 20 January 2014 - Published in Biogeosciences Discuss.: 18 February 2014

Revised: 9 July 2014 - Accepted: 15 January 2015 - Published: 12 February 2015

\begin{abstract}
Large trees are important and unique organisms in forests, providing ecosystem services including carbon dioxide removal from the atmosphere and long-term storage. Some reports have raised concerns about the global decline of large trees. Based on observations from two regions in Finland and three regions in the United States we report that trends of large trees during recent decades have been surprisingly variable among regions. In southern Finland, the growing stock volume of trees larger than $30 \mathrm{~cm}$ at breast height increased nearly five-fold during the second half of the 20th century, yet more recently ceased to expand. In the United States, large hardwood trees have become increasingly common in the Northeast since the 1950s, while large softwood trees declined until the mid 1990s as a consequence of harvests in the Pacific region, and then rebounded when harvesting there was reduced. We conclude that in the regions studied, the history of land use and forest management governs changes of the diameter-class distributions of tree populations. Large trees have significant benefits; for example, they can constitute a large proportion of the carbon stock and affect greatly the carbon density of forests. Large trees usually have deeper roots and long lifetimes. They affect forest structure and function and provide habitats for other species. An accumulating stock of large trees in existing forests may have negligible direct biophysical effects on climate through transpiration or forest albedo. Understanding changes in the demography of tree populations makes a contribution to estimating the past impact and future potential of forests in the global carbon budget and to assessing other ecosystem services of forests.
\end{abstract}

\section{Introduction}

Carbon, which is removed from the atmosphere by forest ecosystem processes, is stored both in vegetation and soils (e.g., McGuire et al., 2001). If carbon stocks of ecosystems build up, the carbon content of the atmosphere is reduced accordingly. Conversely, if the rate of carbon accumulation by ecosystems were to diminish, the rate of increase of carbon dioxide in the atmosphere would be much faster than currently observed (Reich, 2011). The large potential of trees for either removing $\mathrm{CO}_{2}$ from the atmosphere or adding it was discovered in early research about forests, the carbon cycle, and climate (Dyson, 1976; Brown and Lugo, 1982; Cooper, 1983; Woodwell et al., 1983). More recently, research has highlighted other mechanisms exploring how forest canopies affect the radiative forcing of the atmosphere by modifying the albedo (Betts, 2000; Lukeš et al., 2014) and evapotranspiration (Swann et al., 2010).

Global forests are extremely diverse and provide a variety of ecosystem services such as carbon sequestration, industrial raw materials, flood and landslide protection, biodiversity preservation, and aesthetic and health benefits (Pan et al., 2013). Forests are usually defined by the presence of trees and absence of non-forest land use, even though trees are also numerous outside forests in savannas, pasture lands, and in suburban areas and green city centers (Nowak and Greenfield, 2012). Large and old trees are exceptional entities in most tree populations and they have unique and special qualities beyond their climate mitigation function; however, there are concerns about human-caused losses of old and large trees of the world (Lindenmayer et al., 2012, 2013; Blicharska and Mikusinski, 2013). 
While covering only about one-quarter of the global land surface, forests dominate the net removal of $\mathrm{CO}_{2}$ from the atmosphere into land ecosystems (Pan et al., 2011a). Live vegetation, mostly trees, accounts for three-quarters of the large and persistent sink of the global forests. The remaining one-quarter is shared by changing stocks of dead wood, litter, soils and harvested wood products (Pan et al., 2011a). Trees contain carbon in stems, branches, foliage, and roots and provide carbon sources for forest soil stocks and microbes, and for export to downstream water and sediments (Richey et al., 2002).

In mix-aged forests, large trees often contribute a significant proportion of aboveground biomass and the carbon density of the site although only a few may be present (Slik et al., 2013; Lutz et al., 2012; Martínez and Alvarez, 1998). Large trees have deep roots, which transfer carbon into the lowest layers of the forest soil. As trees die, the largest individual trees decay most slowly thus maintaining for some time the carbon stocks in snags or coarse woody debris that are standing or lying in forests (Harmon and Hua, 1991; Krankina and Harmon, 1995; Pan et al., 2011a). Harvested trees may be transformed into wood-based products, which contain significant amounts of carbon and are widely used as a sustainable raw material (Skog et al., 2004). Large trees have statistically lower mortality rates compared to small sized trees within a stand (Coomes and Allen, 2007), which affects forest carbon dynamics and successional processes.

To gain knowledge of size distribution of large trees and their long-term dynamics, we usually rely on surveying the demography of tree populations at annual or multi-annual time steps using forest inventory methodology (Lawrence et al., 2010). Forest inventory measurements are not available at the global level. However, regional data and time series are available from selected countries such as Finland and the United States, which can provide multi-decadal statistics on the demography of tree populations and changes of the size distribution of trees. The evolution of forest carbon for Finland and the United States has been described more broadly in Liski et al. (2006) and Birdsey et al. (2006), respectively. The longest time series, to our knowledge, of statistically representative measurements of timber resources is from a subregion in Finland, where the fieldwork was initiated in 1912 (Kauppi et al., 2010). The first national forest inventories from Finland were carried out in the 1920s and 1930s (Ilvessalo, 1927, 1942), and the national forest inventory in the United States was begun in the 1930s (LaBau et al., 2007).

In this study, we selected five case study regions (Fig. 1). This combination of regions was selected noting that (1) a national forest inventory has been carried out in all regions over a period of time of more than 50 years; (2) observations on the growing stock have been published by size classes of trees at intervals of 10 or less years; (3) each region is large and diverse, containing hundreds of thousands of forest stands and, therefore, disturbance anomalies affecting small regions or individual stands do not distort general regional trends, and (4) forest management history differs between the regions and can be placed in the context of forest transition theory (Mather, 1992).

We focus on large trees, broadly defined as the upper end of the size distribution of live trees (greater than 30 or $33 \mathrm{~cm}$ in diameter at breast height (DBH). The objective of this research is to analyze the role of large trees in the evolution of the growing stock in regions within Finland and the United States representing different land management histories using data from statistically designed sample surveys. We discuss the impact of large trees on the carbon budget, albedo and evapotranspiration of forests, and the effect of land management on the stock of large trees.

\section{Materials and methods}

Forest inventory is based on measurements taken from a statistically representative sample of all trees within a forest region - for details of this approach, see Tomppo et al. (2011) and LaBau et al. (2007). Historical inventory data are available at 5-10 year intervals from Finland (Kuusela, 1972, 1978; Kuusela and Salminen, 1991; Tomppo et al., 2011; Ylitalo, 2013; Korhonen et al., 2013) and decadal intervals from the United States (Smith et al., 2009). We collected data from these published inventories specifically by five regions (Fig. 1). The two regions of Finland combined equal all of Finland, whereas for the United States we selected three diverse regions. We prepared time series estimates of the growing-stock volume of large trees and the distribution of growing-stock volume by tree-size classes. Growing stock-volume (in cubic meters, $\mathrm{m}^{3}$ ) refers to the volume of the tree stem as defined by common merchantability standards. The historical inventories have reported estimates of growing-stock volume by tree-size class based on consistent definitions. We chose to report the distributions as they have been published in the original literature, however, converting inches to centimeters. Future research can easily update the findings of this research as new inventory cycles become completed and published.

Data from Finland referred to nine inventory cycles as follows: $\quad 1951-1953 \rightarrow 1960-1963 \rightarrow 1964-1970 \rightarrow 1971-$ $1976 \rightarrow 1977-1984 \rightarrow 1986-1994 \rightarrow 1996-2003 \rightarrow 2004-$

$2008 \rightarrow 2009-2012$. Measurement teams travel within and across regions. During some years measurements are taken in southern but not in northern Finland, and vice versa. DBH distributions were constructed to separate cohorts of trees representing different size classes. The total stem volume (in millions of $\mathrm{m}^{3}$ ) was estimated for trees within each size cohort and each region. Forests cover a land area of about 11.5 and 11.3 million hectares; in southern Finland and northern Finland, respectively.

Even though the two regions are within one country the land management history varies greatly between the two regions. The main part of rural lands in southern Finland has 


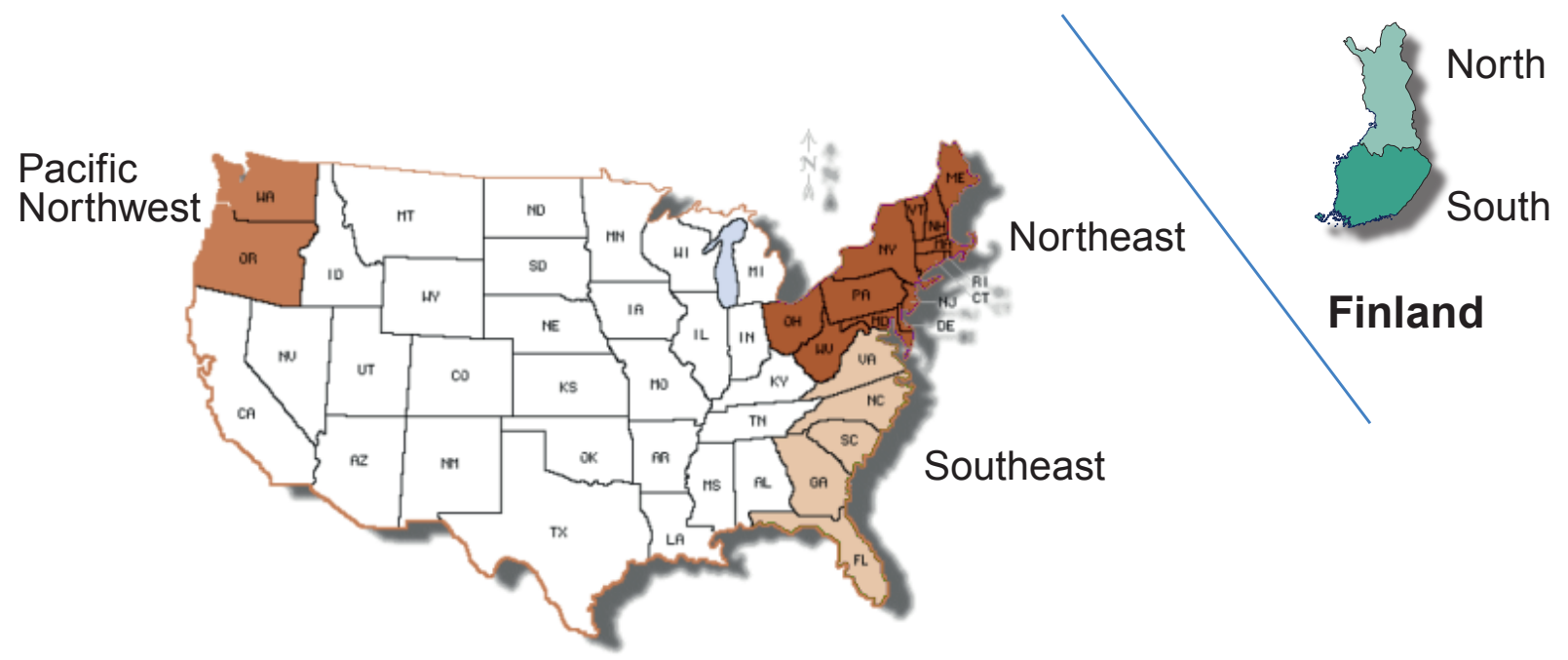

\section{United States}

Figure 1. The location of the study regions in the United States and Finland.

been in private ownership since the middle ages. Forests in southern Finland were severely over harvested in the 19th to early 20th century. In northern Finland, the lands are largely state owned. Industrial forest harvests were common in southern Finland through the 20th century, while they rarely occurred in northern Finland before the 1950s.

The data from the United States covered the period 19532007, and contained five inventory cycles. Three regions within the United States were selected for more detailed analysis covering a total of 91 million hectares (Fig. 1; Table 1). For comparison, the total forest area of the United States in 2007 was 304 million hectares. The selected regions represent the diverse history of land management and impacts on large trees: the Northeast which is largely composed of forests that are re-growing on agricultural land that was abandoned over the last century; the Southeast where much of the forest land is intensively managed on short rotations for timber products; and the Pacific Northwest where old-growth forests were still being cleared and regenerated through the mid-1980s but have since been preserved.

\section{Results}

\subsection{Results for Finland}

The growing stock of Finland's forests consisted predominantly of small and medium sized trees $(<30 \mathrm{~cm} \mathrm{DBH})$. The rate of biomass accumulation was almost the same in southern Finland as in northern Finland, but there were interesting differences between the two regions in the evolution of the tree size distributions over time. The stock of large trees hardly changed in northern Finland, where the accumulation of biomass and carbon was concentrated in small trees of less than $30 \mathrm{~cm}$ in DBH. In contrast in southern Finland, the growing stock of large trees increased nearly five-fold from about 70 to 340 million $\mathrm{m}^{3}$ between 1951-1953 and 20092012 (Fig. 2).

\subsection{Results for the United States}

Trees in the United States are larger on average than those in Finland. In the Pacific Northwest region which is dominated by softwood species and has the largest population of larger trees in the United States, there is a distinct pattern of change over time in the growing stock of trees greater than $33 \mathrm{~cm}$ compared with trees less than $33 \mathrm{~cm}$. The stock declined from 3.7 billion $\mathrm{m}^{3}$ in 1953 to 3.0 billion $\mathrm{m}^{3} 1987$ and then nearly recovered to their prior stocking by 2007 , reaching 3.4 billion $\mathrm{m}^{3}$ (Fig. 3). In contrast, the growing stock of trees less than $33 \mathrm{~cm}$ increased from 1953 to 1977 and then stabilized at about 1.1 billion $\mathrm{m}^{3}$. In the Southeast United States, the growing stock of trees greater than $33 \mathrm{~cm}$ doubled between 1953 and 2007, while that of trees less than $33 \mathrm{~cm}$ increased only until 1977 then was relatively stable (Fig. 3). These changes reflect the increasing influence of industrial plantation forestry over the period. In the Northeast United States where hardwoods predominate, the pattern is similar to the Southeast except that the growing stock of trees greater than $33 \mathrm{~cm}$ more than tripled between 1953 and 2007, indicating forests that are increasing in age coupled with the absence of significant harvesting or stand-replacing natural disturbances. Compared with the Southeast where growingstock increases have leveled off, the total volume of growing stock in the Northeast has continued to increase in recent years. The Northeast has not had such a widespread conversion to intensive forest management as has happened in the Southeast. 
Table 1. Statistics and forest management history of the sub regions addressed in this research. Forest area estimates for Finland include poorly productive land called scrubland (Smith et al., 2009; Ylitalo, 2013).

\begin{tabular}{|c|c|c|c|c|}
\hline Region & $\begin{array}{l}\text { Forest area } \\
(1000 \text { ha) }\end{array}$ & $\begin{array}{l}\text { Stem volume } \\
\left(\text { million } \mathrm{m}^{3}\right)\end{array}$ & $\begin{array}{l}\text { Biomass ( } \mathrm{Tg} \mathrm{C} \\
\text { aboveground) }\end{array}$ & Forest management history \\
\hline US Northeast & 34316 & 3896 & 2041 & $\begin{array}{l}\text { Most forests cleared for agriculture by } \\
1850 \text {; current forests regrowing after } \\
\text { agricultural abandonment }\end{array}$ \\
\hline US Southeast & 35567 & 3589 & 1873 & $\begin{array}{l}\text { Most forests cleared for agriculture by } \\
1850 \text {; current forests regrowing or re- } \\
\text { planted after agricultural abandonment }\end{array}$ \\
\hline US Northwest & 21225 & 4499 & 1561 & $\begin{array}{l}\text { Most forests harvested for wood prod- } \\
\text { ucts during the } 20 \text { th century; harvesting } \\
\text { of old-growth suspended in the } 1980 \text { s }\end{array}$ \\
\hline Finland north & 11258 & 786 & 227 & $\begin{array}{l}\text { Forest land largely state owned. Forest } \\
\text { and land management intensified after } \\
1950\end{array}$ \\
\hline Finland south & 11501 & 1546 & 418 & $\begin{array}{l}\text { Most forests privately owned and re- } \\
\text { covering from severe degradation of the } \\
19 \text { th and early 20th century }\end{array}$ \\
\hline
\end{tabular}
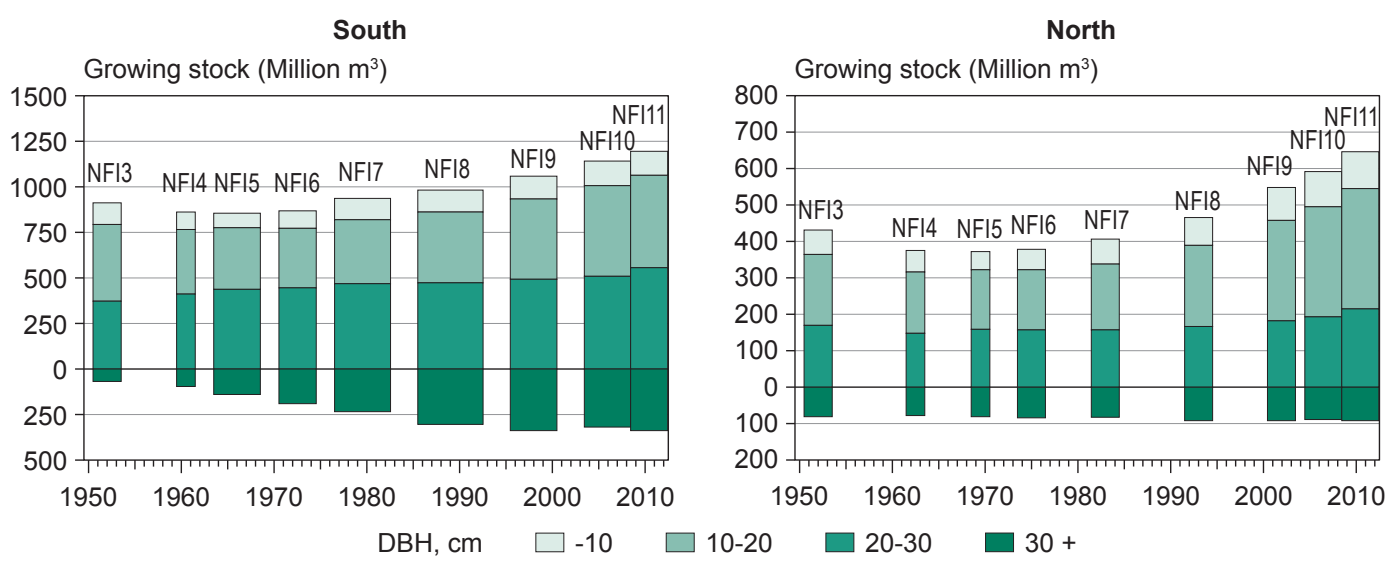

Figure 2. Dynamics of growing stock by tree size classes in regions "south" and "north" of Finland. NFI3 to NFI11 refer to the national forest inventory cycles from the 3rd to 11th cycle over the time span 1951 to 2012. The width of the bars refers to the observation years of each inventory cycle within the region. The stock of small trees is shown above the horizontal axis $(\mathrm{DBH}<30 \mathrm{~cm})-$ with the main change in north Finland beginning in the 1980s. The stock of large trees is shown in positive numbers below the horizontal axis $(\mathrm{DBH}>30 \mathrm{~cm})-$ with the main change in south Finland from 1951 to 1990.

\section{Discussion}

Forest biomass and the carbon stock have expanded even though the global forest area keeps decreasing (Pan et al., 2011a). Globally, forest vegetation has become increasingly dense (Rautiainen et al., 2011). This research indicates that, in Finland and the United States, carbon is sequestered in most size classes of trees, and in four of the five regions studied, the increasing volume of larger trees has made an important contribution to biomass expansion and the sequestration of carbon.
We selected our five study regions for four reasons. First, they are rare exceptions in global forests where reliable monitoring of the growing stock has occurred consistently over 6 decades based on forest inventory methodology. Second, they have been intensively managed with land use policies and practices changing over time. Third, the regions are sufficiently large and diverse for seeing the "forest from the trees", with each region containing hundreds of thousands of individual forest stands thus offering a firm basis for analyzing long-term forest trends. Fourth, they represent different biomes and climate conditions and are suitable for 

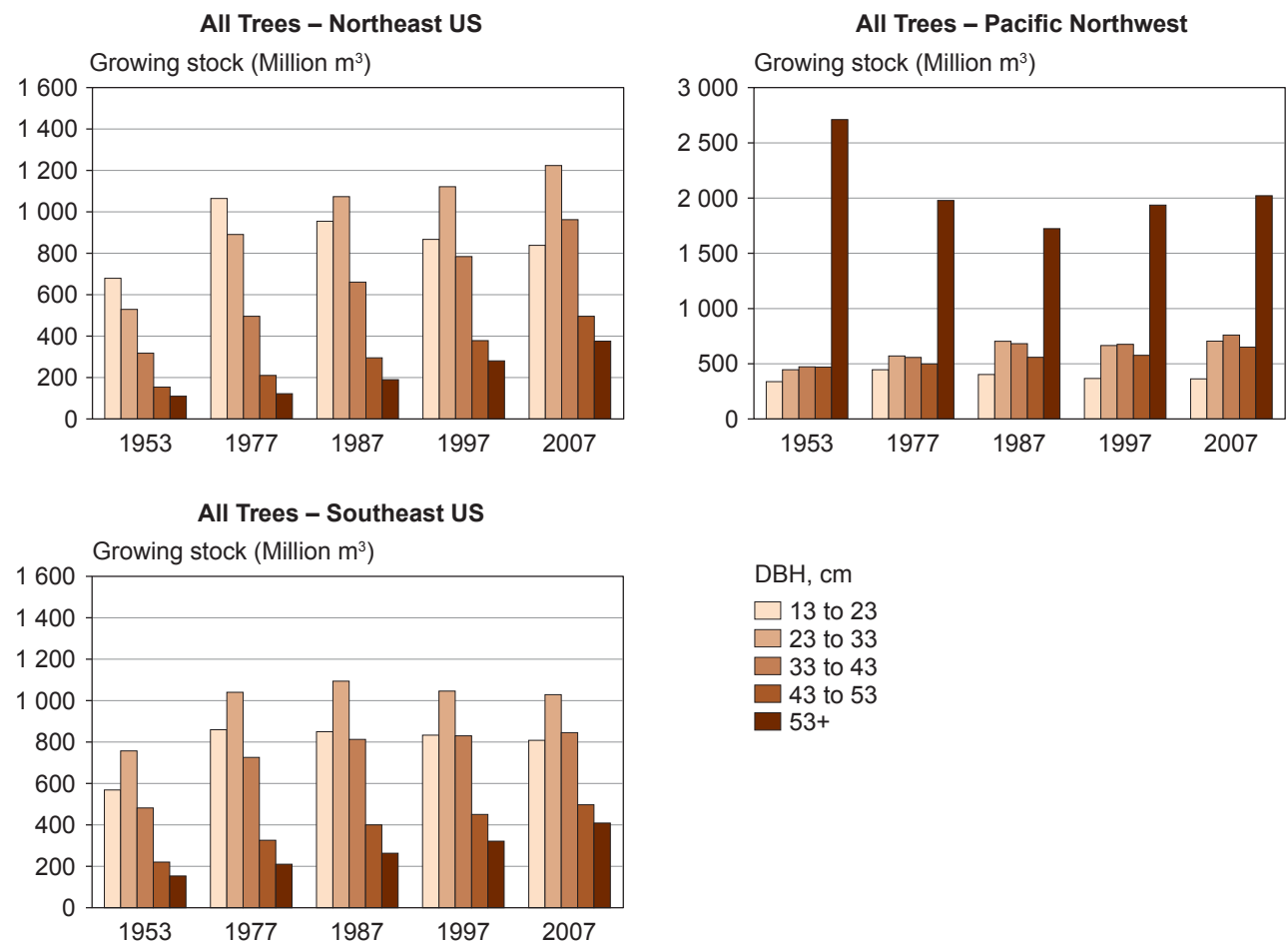

Figure 3. The distribution of growing stock by the size classes from 1953 to 2007 in regions within the United States.

discussing impacts of land management versus those of climate change or $\mathrm{CO}_{2}$ fertilization on forest ecosystems. We used size cohort thresholds as they have been reported in the original statistical publications. This is transparent and paves the way for future studies, as the trends can be easily followed when new data become published.

In temperate zones and also in the boreal forests of Finland, the vegetation cover has been greatly altered by human activities (Pan et al., 2013; Fritzbøger and Søndergaard, 1995). The current forest demography and tree-size distributions generally reflect a disturbance legacy of land-use history (Clawson, 1979; Kauppi et al., 2006; Pan et al., 2011b). In general, the historical switch in industrial countries from subsistence agriculture to modern farming many decades ago affects contemporary forests. Forest transition has occurred from shrinking to expanding forest area (Mather, 1992). Land abandonment has no immediate impact on the populations of large trees within forests. Therefore, agricultural policy is less important than forest policy in affecting the evolution of large tree cohorts. In the United States, beginning 100 years or so ago, Northeastern forests began regrowing on abandoned agricultural land and now these forests have reached an age where large trees are becoming common once again (Pan et al., 2011b). In the Pacific Northwest, large trees were still being harvested in large quantities until about 25 years ago so their numbers were declining, but now that trend has been reversed with most remaining old-growth forest areas set aside for other purposes besides timber production.
Even though our study regions are large and diverse, they do not represent a global "average forest". For example, fire management, which are very important in many other parts of the World have been a significant issue only in parts of our study regions in the Pacific Northwest and Southeast United States. From these results we cannot extrapolate the role of large trees in the global carbon budget, because our study regions cover only $3 \%$ of the area of global forested land as estimated by the FAO. We might try to make such an extrapolation effort, if the trends of large trees had been uniform in all regions. But we observed deviating trends between the regions and changes of biomass accumulation over time responding to land management history. All areas addressed in this study have been used intensively for industrial round wood production. This economic interest has supported the maintenance of the relatively expensive national forest inventories. Without the exceptionally persistent, accurate, and precise forest data, we could not have carried out this research.

Information on the growing stock of tree stems is directly relevant in carbon research, because the volume of growing stock is correlated with the carbon stock in forest biomass. The ratio of carbon stock/growing stock decreases with tree size; in other words, the contribution of stem biomass becomes increasingly large as trees grow in size (e.g., Lehtonen et al., 2004; Jalkanen et al., 2005; Kauppi et al., 2006). A key concept in this conversion is biomass expansion factor (BEF), which has been empirically determined for many 
tree species and for many regions of the world. An analysis for Finland is available in Eerikäinen (2009) and in Härkönen et al. (2011), and for the US in Smith et al. (2007). Taking Finland as an example, the biomass for each tree component is modeled by the main tree species (Repola, 2008, 2009). Thereafter, BEFs were calculated by dividing total tree biomass by stem volume within tree diameter classes (Lehtonen et al., 2004). Typically, for conifers in Finland, $1 \mathrm{~m}^{3}$ of stem wood volume including bark corresponds to a whole tree biomass of 0.6 to $0.8 \mathrm{Mg}$ dry matter. The carbon concentration of dry woody biomass is 45 to $50 \%$ (Lehtonen et al., 2004).

Although large trees have been recognized for their special role in sequestering and storing carbon in forests (Stephenson et al., 2014), the interaction of forests with the climate system is not restricted to the exchange of carbon dioxide between the ecosystem and the atmosphere. In high latitudes as forest biomass expands in areas with low carbon density, the beneficial climate impact of carbon sequestration may be offset by the detrimental effects of decreasing albedo and increasing transpiration on radiative forcing (Betts, 2000; Bonan, 2008; Swann et al., 2010). The good news about the expansion of large trees on existing forest areas is that it favors carbon sequestration inside the surface layer of tree stems rather than adding incremental leaf biomass. The latter more directly affects canopy transpiration and albedo.

\section{Conclusions}

Land management has been a key driver in the change in the stocks of large trees across the regions addressed in this study, covering a total of 122 million hectares of forested land. The contribution of large tree cohorts to biomass expansion and thus carbon sequestration varied greatly in time and space. Only in north Finland was the quantitative contribution of large trees to carbon sequestration insignificant. It was important in the other four regions. For instance, in the eastern US the stock of large hardwood trees expanded and sequestered carbon effectively.

The evolution of the stock of large tree cohorts was affected by management decisions such as the harvest moratorium in the Pacific Northwest US in the early 1990s. As the patterns of large trees varied between regions and fluctuated over time they cannot be explained by changes in climate or $\mathrm{CO}_{2}$ fertilization, which have evolved gradually over all regions. The results of this study should be interpreted with caution regarding less managed forests of the world, but similar regions exist in North America, Europe, Asia, and parts of the Southern Hemisphere where land management decisions have greatly affected the presence of large trees. Nevertheless, managing the stocks of large trees is an option for climate policy and can also be harmonized with opportunities for providing other important ecosystem services. It will be beneficial to many studies on topics such as forest carbon, forest restoration and conservation if monitoring trends of large trees can be achieved globally in the future for forested regions noting also the demography of large trees outside forests on pasture lands and in suburban areas.

Acknowledgements. The authors thank the Maj and Tor Nessling Foundation and the Finnish Society for Sciences and Letters for financial support; the national forest inventories of Finland and the US for collecting, compiling, and publishing the original data; and Sari Elomaa for finalizing the illustrations.

Edited by: N. Zeng

\section{References}

Betts, R. A.: Offset of the potential carbon sink from boreal forestation by decreases in surface albedo, Nature, 408, 187-190, 2000.

Birdsey, R., Pregitzer, K., and Lucier, A.: Forest carbon management in the United States 1600-2100, J. Environ. Qual., 35, 1461-1469, 2006.

Blicharska, M. and Mikusinski, G.: Old trees: cultural value, Science, 339, 904, 2013.

Bonan, G. B.: Forests and climate change: forcings, feedbacks, and the climate benefits of forests, Science, 320, 1444-1449, 2008.

Brown, S. and Lugo, A. E.: The storage and production of organic matter in tropical forests and their role in the global carbon cycle, Biotropica, 14, 161-187, 1982.

Clawson, M.: Forests in the long sweep of American history, Science, 204, 1168-1174, 1979.

Coomes, D. A. and Allen, R. B.: Mortality and tree-size distributions in natural mixed-age forests, J. Ecology, 95, 27-40, 2007.

Cooper, C. F.: Carbon storage in managed forests, Can. J. Forest Res., 13, 155-166, 1983.

Dyson, F. J.: Can we control carbon dioxide in the atmosphere?, Energy, 2, 287-291, 1976.

Eerikäinen, K.: A multivariate linear mixed-effects model for the generalization of sample tree heights and crown ratios in the Finnish National Forest Inventory, Forest Sci., 55, 480-493, 2009.

Fritzbøger, B. and Søndergaard, P.: A short history of forest uses, In: Multiple-Use Forestry in the Nordic Countries, edited by: Hytönen, M., METLA, Finnish Forest Research Institute, Helsinki Research Centre, 11-41, 1995.

Härkönen, S., Lehtonen, A., Eerikäinen, K., Peltoniemi, M., and Mäkelä, A.: Estimating forest carbon fluxes for large regions based on process-based modelling, NFI data and Landsat satellite images, Forest Ecol. Manag., 262, 2364-2377, 2011.

Harmon, M. E. and Hua, C.: Coarse woody debris dynamics in two old-growth ecosystems, BioScience, 41, 604-610, 1991.

Ilvessalo, Y.: Results of national forest inventory 1921-24, Communicationes Instituti Forestalis Fenniae, 11, 1-613, 1927 (in Finnish with English summary).

Ilvessalo, Y.: The forest resources and the condition of the forests of Finland: the Second National Forest Survey, Communicationes Instituti Forestalis Fenniae, 30, 1-446, 1942 (in Finnish with English summary). 
Jalkanen, A., Petersson, H., Mäkipää, R., Ståhl, G., and Lehtonen, A.: Estimation of the biomass stock of trees in Sweden: comparison of biomass equations and age-dependent biomass expansion factors, Ann. Forest Sci., 62, 845-851, 2005.

Kauppi, P. E., Ausubel, J. H., Fang, J., Mather, A. S., Sedjo, R. A., and Waggoner, P. E.: Returning forests analyzed with the forest identity, P. Natl. Acad. Sci. USA, 103, 17574-17579, 2006.

Kauppi, P. E., Rautiainen, A., Korhonen, K. T., Lehtonen, A., Liski, J., Nöjd, P., and Virtanen, T.: Changing stock of biomass carbon in a boreal forest over 93 years, Forest Ecol. Manag., 259, 12391244, 2010.

Korhonen, K. T., Ihalainen, A., Viiri, H., Heikkinen, J., Henttonen, H. M., Hotanen, J.-P., Mäkelä, H., Nevalainen, S., and Pitkänen, J.: Suomen metsät 2004-2008 ja niiden kehitys 1921-2008, Metsätieteen aikakauskirja, 3, 269-608, 2013 (in Finnish).

Krankina, O. N. and Harmon, M. E.: Dynamics of the dead wood carbon pool in northwestern Russian boreal forests, in: Boreal Forests and Global Change, Springer Netherlands, 227-238, 1995.

Kuusela, K.: Forest resources and ownership in Finland 196470 and their development 1920-70, Communicationes Instituti Forestalis Fenniae, 76, 1-126, 1972 (in Finnish with English summary).

Kuusela, K.: Forest resources and ownership in Finland 1971-1976, Commun. Inst. For. Fenn., 93, 1-107, 1978 (in Finnish with English summary).

Kuusela, K. and Salminen, S.: Forest resources of Finland in 19771984 and their development 1952-1980, Acta Forestalia Fennica, 220, 1-84, 1991 (in Finnish with English summary).

LaBau, V. J., Bones, J. T., Kingsley, N. P., Lund, H. G., and Smith, W. B.: A history of the forest 5 survey in the United States: 1830 2004, FS-877, US Department of Agriculture, Forest Service, Washington DC, 82 pp., 2007.

Lawrence, M., McRoberts, R. E., Tomppo, E., Gschwantner, T., and Gabler, K.: Comparisons of national forest inventories, in: National Forest Inventories, Springer Netherlands, 19-32, 2010.

Lehtonen, A., Mäkipää, R., Heikkinen, J., Sievänen, R., and Liski, J.: New approach to formulate biomass expansion factors (BEF) by stand age for Scots pine, Norway spruce and birch, Forest Ecol. Manage, 188, 211-224, 2004.

Lindenmayer, D. B., Laurance, W. F., and Franklin, J. F.: Global decline in large old trees, Science, 338, 1305-1306, 2012.

Lindenmayer, D. B., Laurance, W. F., Franklin, J. F., Likens, G. E., Banks, S. C., Blanchard, W., Gibbons, P., Ikin, K., Blair, D., McBurney, L., Manning, A. D. and Stein, J. A. R.: New policies for old trees: averting a global crisis in a keystone ecological structure, Conservation Letters, 7, 61-69, 2013.

Liski, J., Lehtonen, A., Palosuo, T., Peltoniemi, M., Eggers, T., Muukkonen, P., and Mäkipää, R.: Carbon accumulation in Finland's forests 1922-2004 - an estimate obtained by combination of forest inventory data with modelling of biomass, litter and soil, Ann. For. Sci., 63, 687-697, 2006.

Lukeš, P., Rautiainen, M., Manninen, T., Stenberg, P., and Mõttus, M. Geographical gradients in boreal forest albedo and structure in Finland, Remote Sens. Environ., 152, 526-535, 2014.

Lutz, J. A., Larson, A. J., Swanson, M. E., and Freund, J. A.: Ecological importance of large-diameter trees in a temperate mixed-conifer forest, PLoS ONE, 7, e36131, doi:10.1371/journal.pone.0036131, 2012.
Mather, A. S.: The forest transition, Area, 24, 367-379, 1992.

Martínez, M. and Alvarez, E. R.: How old are tropical rain forest trees?, Trends Plant Sci., 3, 400-405, 1998.

McGuire, A. D., Sitch, S., Clein, J. S., Dargaville, R., Esser, G., Foley, J., and Wittenberg, U.: Carbon balance of the terrestrial biosphere in the twentieth century: analyses of $\mathrm{CO}_{2}$, climate and land use effects with fourprocess-based ecosystem models, Global Biogeochem. Cy., 30, 183-206, 2001.

Nowak, D. J. and Greenfield, E. J.: Tree and impervious cover change in US cities, Urban For. Urban Gree., 11, 21-30, 2012.

Pan, Y., Birdsey, R. A., Fang, J., Houghton, R., Kauppi, P. E., Kurz, W. A., Phillips, O. L., Shvidenko, A., Lewis, S. L., Canadell, J. G., Ciais, P., Jackson, R. B., Pacala, S. W., McGuire, A. D., Piao, S. L., Rautiainen, A., Sitch, S., and Hayes, D.: A large and persistent carbon sink in the world's forests, Science, 333, 988993, 2011a.

Pan, Y., Chen, J. M., Birdsey, R., McCullough, K., He, L., and Deng, F.: Age structure and disturbance legacy of North American forests, Biogeosciences, 8, 715-732, doi:10.5194/bg-8-7152011, 2011b.

Pan, Y., Birdsey, A. R., Philipps, O. L., and Jackson, B. R.: The structure, distribution and biomass of the world's forests, Annu. Rev. Ecol. Evol. S., 44, 593-662, 2013.

Rautiainen, A., Wernick, I., Waggoner, P. E., Ausubel, J. H., and Kauppi, P. E.: A national and international analysis of changing forest density, PLoS ONE, 6, 19577, doi:10.1371/journal.pone.0019577, 2011.

Reich, P.: Taking stock of forest carbon, Nature Climate Change, 1, 346-347, 2011.

Repola, J.: Biomass equations for birch in Finland, Silva Fenn., 42, 605-624, 2008.

Repola, J.: Biomass equations for Scots pine and Norway spruce in Finland, Silva Fenn., 43, 625-647, 2009.

Richey, J., Melack, J., Aufdenkampe, A., Ballester, V., and Hess, L.: Outgassing from Amazonian rivers and wetlands as a large source of tropical CO2, Nature, 416, 617-620, 2002.

Skog, K. E., Pingoud, K., and Smith, J. E.: A method countries can use to estimate changes in carbon stored in harvested wood products and the uncertainty of such estimates, Environ. Manage., 33, 65-73, 2004.

Slik, J. W. F., Paoli, G., McGuire, K., Amaral, I., and Barroso, J.: Large trees drive forest aboveground biomass variation in moist lowland forests across the tropics, Global. Ecol. Biogeogr., 22, 1261-1271, 2013.

Smith, J. E., Heath, L. S., and Nichols, M. C.: US forest carbon calculation tool: forest-land carbon stocks and net annual stock change. Revised. Gen. Tech. Rep. NRS-13, U.S. Dep. Agric. For. Serv., 34 pp., Newtown Square, PA, 2007.

Smith, W. B., Miles, P. D., Perry, C. H., and Pugh, S. A.: Forest resources of the United States, RPA assessment, Gen. Tech. Rep. WO-78, US Dep. of Agric. For. Serv., Washington DC, 2009.

Stephenson, N. L., Das, A. J., Condit, R., Russo, S. E., Baker, P. J., Beckman, N. G., Coomes, D. A., Lines, E. R., Morris, W. K., Ruger, N., Alvarez, E., Blundo, C., Bunyavejchewin, S., Chuyong, G., Davies, S. J., Duque, A., Ewango, C. N., Flores, O., Franklin, J. F., Grau, H. R., Hao, Z., Harmon, M. E., Hubbell, S. P., Kenfack, D., Lin, Y., Makana, J.-R., Malizia, A., Malizia, L. R., Pabst, R. J., Pongpattananurak, N., Su, S.-H., Sun, I-F., Tan, S., Thomas, D., van Mantgem, P. J., Wang, X., Wiser, S. K. 
and Zavala, M. A.: Rate of tree carbon accumulation increases continuously with tree size, Nature, 507, 90-93, 2014.

Swann, A. L., Fung, I. Y., Levis, S., Bonan, G. B., and Doney, S. C.: Changes in Arctic vegetation amplify high-latitude warming through the greenhouse effect, P. Natl. Acad. Sci. USA, 107, 1295-1300, 2010.

Tomppo, E., Heikkinen, J., Henttonen, H. M., Ihalainen, A., Katila, M., Mäkelä, H., Tuomainen, T., and Vainikainen, N.: Designing and Conducting a Forest Inventory - Case: 9th National Forest Inventory of Finland, Springer, Heidelberg, 270 pp., 2011.
Woodwell, G. M., Hobbie, J. E., Houghton, R. A., Melillo, J. M., Moore, B., Peterson, B. J., and Shaver, G. R.: Global deforestation: contribution to atmospheric carbon dioxide, Science, 222, 1081-1086, 1983.

Ylitalo, E.: Finnish Statistical Yearbook of Forestry, Finland 2013, METLA, 2013. 